\title{
Effect of Different Nutrient Solubilizers on the Productivity and Economics of Grain Oat (Avena sativa L.)
}

\author{
Jagadish Jena ${ }^{1}$, Narayan Chandra Sarkar ${ }^{1 *}$, Chinmoy Sen ${ }^{1}$, Y. V. Singh ${ }^{2}$ and Mrinmoy Karmakar ${ }^{1}$ \\ ${ }^{1}$ Dept. of Agronomy, Institute of Agriculture, Sriniketan, Dist. Birbhum, West Bengal (731 236), India \\ ${ }^{2}$ Division of Microbiology, Indian Agricultural Research Institute, New Delhi (110 012), Inia
}

\begin{tabular}{l} 
Corresponding Author \\
\hline \hline Narayan Chandra Sarkar \\
e-mail: narayanchandra.sarkar@visva-bharati.ac.in
\end{tabular}

\section{Abstract}

Oat is one of the important fodder crops widely grown during winter season for grain purpose as well as green fodder in different parts of the World. The experiment was conducted during rabi seasons of 2014-15 and 2015-16 at Agricultural research farm, Institute of Agriculture (Palli Siksha Bhavana), Sriniketan, West Bengal, India for studying the effect of nutrient solublizers combination with on growth, productivity and economics on grain oat. The treatments consists of eleven treatments including absolute control viz., recommended N:P:K:Zn (80:40:40:20 kg ha $\left.{ }^{-1}\right)$; Azotobacter+75\% N+recommended P, K, Zn; Azotobacter+PSB+75\% N \& P+recommended $\mathrm{K}, \mathrm{Zn}$; Azotobacter+PSB+KSB+75\% N, P \& K+recommended Zn; Azotobacter+PSB+KSB+ZnSB+75\% N, P, K \& Zn; Azotobacter+KSB+75\% N \& K+recommended P \& Zn; Azotobacter $+Z n S B+75 \%$ N \& Zn+recommended P \& K; PSB+KSB+75\% P \& K+recommended N \& Zn; PSB+ZnSB+75\% $P \& Z n+$ recommended N \& K; KSB+ZnSB+75\% K \& Zn+recommended N \& P. The experiment, was laid out in randomized block design (RBD) with each treatment replicated thrice.The results revealed that application of Azotobacter+PSB+KSB+ZnSB+75\% N, P, K \& Zn exhibited highest dry matter, number of panicles $\mathrm{m}^{-2}$, grain yield, straw yield and biological yield of oat grain production. This was closely followed by other treatments with biofertilizers. The highest gross return, net return and return rupee ${ }^{-1}$ investment in oat grain cultivation were achieved from the same treatment followed by Azotobacter+PSB+KSB+75\% N, P \& K+recommended Zn.

Keywords: Oat, biofertilizer, yield, economics

\section{Introduction}

Oat (Avena sativa L.), locally known as jai is an important nonlegume, wintercereal crop, grown under irrigated conditions of northern and north-western regions of India. The oat is now being preferred as a "functional food" (food for good health) as it is a rich source of dietary fibers, $\beta$-glucan, minerals and also has antioxidant properties. It is consumed primarily as a breakfast cereal. The consumption of oat leads to lowering of low density lipoprotein (LDL) cholesterol which assures safety against heart diseases, regulates blood sugar level in diabetics (Tapola et al., 2005) and also manages gastro-intestinal health and obesity (Zdunczyk et al., 2006). The increasing awareness about health-related benefits and varied industrial uses of this crop have also raised hopes for a boost in their production. Besides there is tremendous pressure of livestock on the available total feed and fodder, as land available for fodder production has been decreasing. The country faces a net deficit of $63 \%$ green fodder, $24 \%$ dry crop residues and $64 \%$ feeds (Kumar et al., 2012). Half of the total losses in livestock productivity are contributed to by the inadequacy in supply of feed and fodder (Anonymous, 2013).India ranks sixth in World cereal production following wheat, maize, rice, barley and sorghum. The total area covered under oat cultivation in the country is about 1.0 million ha with $35-50 \mathrm{t} \mathrm{ha}^{-1}$ green fodder productivity (Anonymous, 2011).

Growth of plant is directly related to the nutrient supply and if it is in the integrated form, it adds more to growth. Oat ( $A$. sativa L.) is an important fodder crop and is fast growing and high yielding crop thus requires a large quantity of fertilizers $\mathrm{N}$ for enhancing production of quality of herbage (Singh and Dubey, 2007). It is an exhaustive crop considering its nutrient demand and puts heavy nutritional load on soil.The inorganic fertilizers are required to maintain soil fertility and sustainable agriculture systems. The fertilizers are required for enhancing soil productivity. The price of these is lower and The price is their uses give immediate result, which make them more acceptable by farmers (Bokhtiar and Sakurai, 2005). High inputs of chemical fertilizers during last 150 years have not only left soils degraded, polluted and less productive but have also posed severe health and environmental hazards. Organic 
farming methods such as the use of biofertilizers would solve these issues and make the ecosystem healthier. Use of soil microorganism as inoculants (biofertilizers) constitutes an important component of integrated nutrient management that leads to sustainable agriculture. Biofertilizers play a very significant role in improving soil fertility by fixing atmospheric nitrogen, both, in association with plant roots and without it, solubilize insoluble soil phosphates and produces plant growth substances in the soil. Inoculants present in biofertilizers include mainly the nitrogen fixing, phosphate solubilizing and plant growth promoting microorganisms (Goel et al., 1999).There are different types of important microorganisms including nitrogen fixers and phosphate solubilizers such as Azotobacter, Phosphate-Solubilizing Bacteria (PSB), Potash Solubilizing Bacteria (KSB) and Zinc solubilizing bacteria (ZnSB).The nitrogen fixers like Rhizobium spp., Azospirillum spp., Azotobacter spp., BGA and Phosphate solubilizing bacteria like Bacillus magatherium, Pseudomonas striata and phosphate mobilizing mycorrhiza have been widely accepted as biofertilizers (Subba Rao, 2001a). Keeping all these ideas in view the present experiment was carried out for studying the effect of biofertilizers on the productivity and economics of oat cultivation.

\section{Materials and Methods}

The experiment was conducted during Rabi seasons of 201415 and 2015-16 at Agriculturalresearch farm, Palli Siksha Bhavana, Sriniketan, West Bengal, India. The farm was situated at $23^{\circ} 39^{\prime} \mathrm{N}$ latitude and $87^{\circ} 42^{\prime} \mathrm{E}$ longitudes with an average altitude of $58.90 \mathrm{~m}$ above mean sea level under semi-arid region of West Bengal. The soil of the experimental plot was sandy loam in texture, acidic in soil reaction. The experiment consists of eleven treatments, was laid out in randomized block design (RBD) with each treatment replicated thrice. The treatment details were $\mathrm{T}_{1}$ : Absolute Control, $\mathrm{T}_{2}$ : Recommended $\mathrm{N}: \mathrm{P}: \mathrm{K}: \mathrm{Zn}\left(80: 40: 40: 20 \mathrm{~kg} \mathrm{ha}^{-1}\right), \mathrm{T}_{3}$ : Azotobacter $+75 \%$ $\mathrm{N}+$ recommended $\mathrm{P}, \mathrm{K}, \mathrm{Zn}, \mathrm{T}_{4}$ : Azotobacter+PSB+75\% N \& $\mathrm{P}+$ recommended $\mathrm{K}, \mathrm{Zn}, \mathrm{T}_{5}$ : Azotobacter+PSB+KSB+75\% N, P \& $\mathrm{K}+$ recommended $\mathrm{Zn}, \mathrm{T}_{6}$ : Azotobacter+PSB+KSB+ZnSB+75\% $\mathrm{N}, \mathrm{P}, \mathrm{K} \& \mathrm{Zn}, \mathrm{T}_{7}:$ Azotobacter $+\mathrm{KSB}+75 \% \mathrm{~N} \& \mathrm{~K}+$ recommended $P$ \& Zn, $T_{8}$ : Azotobacter+ZnSB+75\% N \& Zn+recommended $P$ \& $K, T_{9}: P S B+K S B+75 \% P$ \& $K+$ recommended $N$ \& $Z n$, $T_{10}: P S B+Z n S B+75 \% P$ \& $Z n+$ recommended $N \& K, T_{11}$ : $\mathrm{KSB}+\mathrm{ZnSB}+75 \% \mathrm{~K} \& \mathrm{Zn}+$ recommended N \& P. The fodder crop oat variety JHO-822 was selected for the study. Destructive samples were taken in each plot at an interval of 30 days starting from 30 days after sowing (DAS), i.e., at 30 DAS, 60 DAS, 90 DAS and at harvest during winter season. The green and senesced leaves and stems were separated and sundried and further dried in a hot-air oven at a temperature of $65^{\circ} \mathrm{C}$ for 72 hour still constant weight was recorded. Then total plant dry weight ( g plant $^{-1}$ ) were calculated out summing up the dry weight of different plant parts and dry matter accumulation in $\mathrm{g} \mathrm{m}^{-2}$ was worked out based on plant density in different plots. Five plants from each plot were randomly selected for measuring length of panicle of oats. The average length of these five plants was considered for calculation of length of panicle for each treatment. In every plot from three places, number of panicles $\mathrm{m}^{2}$ was counted in one meter square area. For each treatment, average number of panicles in one meter square area was then obtained. Five panicles from each plot were randomly selected and number of filled grains per panicle was counted. Thus, for each treatment the average number of filled grains per panicle was counted. The grains counted from five panicles were dried to constant weight and their weights were taken separately from each plot. Then test weight (1000 seed weight) and grain weights for each plot were recorded from the harvested samples of the net plot area earmarked for yield estimation were used for determining the grain yield in $\mathrm{t} \mathrm{ha}^{-1}$.The straws after separating the grains were dried properly and their weights were recorded and converted into $\mathrm{kg} \mathrm{ha}^{-1}$ for each plot. The Harvest Index of Rice was obtained by using the following formula dividing economic yield by biological yield multiplied by 100 .

The economic yield indicates the grain yield, whereas the biological yield represents the total yield of above ground plant parts (both grain and straw) recorded in this experiment. To calculate gross return, net return and return rupee $^{-1}$ invested of different treatments, the cost of various inputs like seed, manure, fertilizers, labour, ploughing, plant protection etc. used in the experiment were calculated as per the available market price. The value of produce like seed and straw was also calculated as per available market price. The prices of the inputs that were prevailing at the time of their use (Appendix III) were utilized for determining the cost of cultivation which was given in rupees per hectare. The model prices of rice prevailing in the market immediately after its harvest were used for the calculation of gross returns. The net return per hectare was worked out by deducting the cost of cultivation from the gross return and expressed in rupees per hectare. In order to find out the economics, the cost of cultivation and the gross return of all the treatments were worked out separately. Dividing this gross return by cost of cultivation, return per rupee invested was obtained.

The analysis of variance method (Cochran and Cox, 1992) was followed to statistically analyse the various data. The significance of different sources of variation was tested by "Error Mean Square Method" of Fisher Snedecor's "F" test at probability level 0.05 . In the summary tables of result, the standard error of means (SEm \pm ) and the value of critical differences (C.D.) between means have been provided.

\section{Results and Discussion}

\subsection{Dry matter accumulation}

The perusal of the data from Figure 1 revealed that treatments had significant influence on plant dry matter accumulation at different stages. At 30 DAS, the treatment 


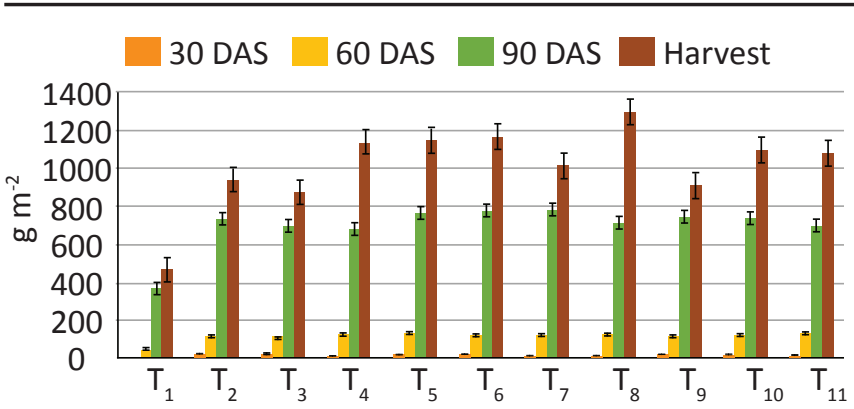

Figure 1: Effect of biofertilizers on dry matter accumulation of oat

Azotobacter+PSB+KSB+ZnSB+75\% N, P, K \& Zn $\left(\mathrm{T}_{6}\right)$ recorded highest dry matter accumulation and lowest value was shown by absolute control $\left(\mathrm{T}_{1}\right)$ plot. This treatment Azotobacter+ $\mathrm{PSB}+\mathrm{KSB}+\mathrm{ZnSB}+75 \% \mathrm{~N}, \mathrm{P}, \mathrm{K} \& \mathrm{Zn}\left(\mathrm{T}_{6}\right)$ resulted significantly higher dry matter accumulation than absolute control $\left(T_{1}\right)$ only. The data on 60 DAS revealed that the highest value was observed with Azotobacter+PSB+KSB+75\% N, P \& K+Recommended $\mathrm{Zn}\left(\mathrm{T}_{5}\right)$ which was significantly higher than absolute control $\left(T_{1}\right)$ plot, recommended N:P:K:Zn (80:40:40:20 kg ha-1) $\left(T_{2}\right)$ and Azotobacter $+75 \% \mathrm{~N}+$ recommended $\mathrm{P}, \mathrm{K}, \mathrm{Zn}\left(\mathrm{T}_{3}\right) .90 \mathrm{DAS}$ data revealed significantly higher dry matter accumulation with Azotobacter+PSB+KSB+ZnSB+75\% N, P, K \& Zn ( $\left.\mathrm{T}_{6}\right)$ over absolute control $\left(\mathrm{T}_{1}\right)$. At harvest, Azotobacter $+\mathrm{ZnSB}+75 \% \mathrm{~N}$ \& $Z n+$ Recommended $P \& K\left(T_{8}\right)$ proved best in dry matter accumulation which was statistically at par with all other treatments except absolute control $\left(\mathrm{T}_{1}\right)$. This treatment $\left(T_{6}\right)$ however gave $144.66 \%$ and $24.09 \%$ higher dry matter accumulation over absolute control $\left(\mathrm{T}_{1}\right)$ and recommended $\mathrm{N}: P: K: Z n\left(80: 40: 40: 20 \mathrm{~kg} \mathrm{ha}^{-1}\right)\left(\mathrm{T}_{2}\right)$, respectively. The above experimental result was in proximity with the findings from Agamy et al. (2012) and Azimzadeh et al. (2012), who depicted about the positive responses of applying biofertilizers with chemical fertilizers in increasing dry matter accumulation.

\subsection{Yield components and yield}

Among the treatments, the highest (179.00) number of panicles recorded with Azotobacter+PSB+KSB+ZnSB+75\% $N, P, K \& Z n$ which was significantly higher than all the treatments (Table 1). However, the second highest number of tillers plant ${ }^{-1}$ (153.00) was recorded with Azotobacter $+\mathrm{PSB}+\mathrm{KSB}+75 \% \mathrm{~N}, \mathrm{P} \& \mathrm{~K}+$ recommended $\mathrm{Zn}$. This result of effect of nutrient management on number of panicles $\mathrm{m}^{-2}$ was the confirmation of results revealed by Abdallah et al. (2013), Mohammed et al. (2012) and Agamy et al. (2012). The perusal of the data revealed that treatments had significant influence on filled grains panicle ${ }^{-1}$ of oat. The highest (74.73) number of filled grains panicle ${ }^{-1}$ was recorded with the treatment with Azotobacter+PSB $+75 \%$ N \& P+recommended $\mathrm{K}, \mathrm{Zn}$ which was significantly higher than absolute control, Azotobacter $+75 \%$ N+recommended P, K, Zn; PSB $+\mathrm{ZnSB}+75 \%$ $P \& Z n+$ recommended $N \& K$ and statistically at par with rest of the treatments. Singh et al. (2005) reported the application of Azotobacter with chemical fertilizers increases the grains panicle ${ }^{-1}$ and this was the conformity of the findings of Sheoran et al. (2000). Increasing filled grain panicle ${ }^{-1}$ on application of biofertilizers combined with chemical fertilizers also reported by Abdallah et al. (2013), Azimadeh et al. (2012), Mohmmed et al. (2012) and Moghadam et al. (2012). All of the previous results were in favour of the result from current experiment showed the increased trend of numbers of fertile seed grains panicle ${ }^{-1}$ when biofertilizers applied in combination with chemical fertilizers. The treatments had no significant influence on length of panicles. The highest $(29.45 \mathrm{~cm})$ panicle length was observed in the treatment with recommended N:P:K:Zn (80:40:40:20 $\left.\mathrm{kg} \mathrm{ha}^{-1}\right)$ followed by Azotobacter+KSB+75\% N \& K+recommended P \& Zn. The

Table 1: Effect of different biofertilizers on yield attributes, yield of oat (pooled data of 2014-15 and 2015-16)

\begin{tabular}{lcccccc}
\hline Treatments & $\begin{array}{c}\text { No. of panicles } \\
\mathrm{m}^{-2}\end{array}$ & $\begin{array}{c}\text { No. of filled grains } \\
\text { panicle }^{-1}\end{array}$ & $\begin{array}{c}\text { Length of pani- } \\
\text { cle }(\mathrm{cm})\end{array}$ & $\begin{array}{c}\text { Test weight } \\
(\mathrm{g})\end{array}$ & $\begin{array}{c}\text { Biological yield } \\
\left(\mathrm{t} \mathrm{ha}^{-1}\right)\end{array}$ & $\begin{array}{c}\text { Harvest } \\
\text { index }\end{array}$ \\
\hline $\mathrm{T}_{1}$ & 113.7 & 43.5 & 25.3 & 27.4 & 2.23 & 0.36 \\
$\mathrm{~T}_{2}$ & 139.3 & 72.6 & 29.5 & 30.82 & 4.64 & 0.38 \\
$\mathrm{~T}_{3}$ & 134.3 & 62.5 & 27.8 & 33.6 & 4.80 & 0.37 \\
$\mathrm{~T}_{4}$ & 151.3 & 74.7 & 28.4 & 32.4 & 6.27 & 0.36 \\
$\mathrm{~T}_{5}$ & 153 & 71.7 & 27.8 & 29.7 & 6.60 & 0.36 \\
$\mathrm{~T}_{6}$ & 179 & 66 & 27.5 & 32.85 & 6.87 & 0.37 \\
$\mathrm{~T}_{7}$ & 138.34 & 68.6 & 28.9 & 30.2 & 5.67 & 0.38 \\
$\mathrm{~T}_{8}$ & 150 & 65 & 27.5 & 31.5 & 5.59 & 0.36 \\
$\mathrm{~T}_{9}$ & 138 & 64.2 & 27.7 & 31 & 5.50 & 0.35 \\
$\mathrm{~T}_{10}$ & 142 & 56.1 & 27.5 & 30.4 & 5.28 & 0.37 \\
$\mathrm{~T}_{11}$ & 139.67 & 64.4 & 28.3 & 27.8 & 4.60 & 0.38 \\
$\mathrm{SEm} \pm$ & 8.45 & 5.03 & 1.66 & 1.245 & 0.40 & 0.02 \\
$\mathrm{CD}(p=0.05)$ & 24.92 & 14.82 & NS & 3.67 & 1.20 & 0.06 \\
\hline
\end{tabular}


treatment with recommended N: P: K: Zn (80:40:40:20) $\left(\mathrm{T}_{2}\right)$ was at par with all treatments except absolute control. The shortest $(25.31 \mathrm{~cm})$ panicle observed with absolute control. There was significant difference in test weight among treated plots. The highest (33.56 g) test weight was observed with the treatment with Azotobacter $+75 \% \mathrm{~N}+$ recommended $\mathrm{P}, \mathrm{K}, \mathrm{Zn}$ (33.56 g) followed by Azotobacter+PSB+KSB+ZnSB+75\% N, P, K \& Zn (32.75 g) and Azotobacter+PSB+75\% N \& P+recommended $\mathrm{K}, \mathrm{Zn}$ (32.40 g). The treatment having Azotobacter $+75 \%$ $\mathrm{N}+$ recommended $\mathrm{P}, \mathrm{K}, \mathrm{Zn}$ was statistically at par with other treatments except treatment having absolute control (27.40 g), Azotobacter+PSB+KSB+75\% N, P \& K+recommended Zn (29.69 g) and KSB+ZnSB+75\% K \& Zn+Recommended N \& $P$ $(27.77 \mathrm{~g})$. On the other hand, Mirshekari et al. (2012) and Mohammed et al. (2012) concluded that rhizobacteria seed priming increased the test weight significantly. On contrary, this result was confirmation of report by Singh et al. (2005). These results were also confirmed by Esmailpour et al. (2013), Mirshekari and Kauchebagh (2013). The current experiment finding was also in favour of results of synergistic effect of biofertilizers with chemical fertilizers on increasing the test weight of grains.

The treatment Azotobacter+PSB+KSB+ZnSB+75\% N, P, K \& $\mathrm{Zn}\left(\mathrm{T}_{6}\right)$ resulted in highest $\left(2.52 \mathrm{t} \mathrm{ha}^{-1}\right)$ grain yield which however statistically at par with Azotobacter+PSB+KSB+75\% $\mathrm{N}, \mathrm{P} \& \mathrm{~K}+$ recommended $\mathrm{Zn}\left(\mathrm{T}_{5}\right)$, Azotobacter+PSB $+75 \%$ $\mathrm{N}$ \& $\mathrm{P}+$ recommended $K, \mathrm{Zn}\left(\mathrm{T}_{4}\right)$ (Figure 2 ). Azotobacter+PSB+KSB+ZnSB+75\% N, P, K \& Zn ( $\left.\mathrm{T}_{6}\right)$ on the other

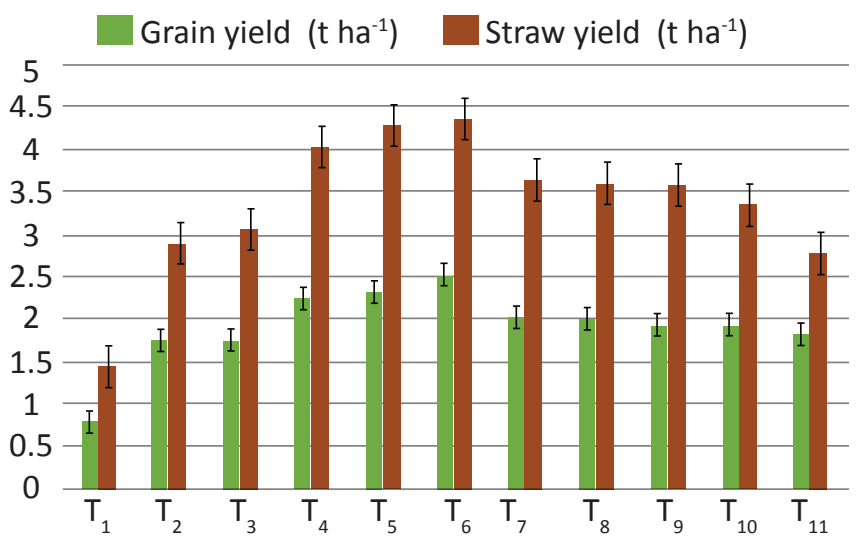

Figure 2: Effect of biofertilizers on grain and straw yield of oat

hand, was recorded $71.15 \%, 36.92 \%$ and $242.31 \%$ higher grain yield over recommended N:P:K:Zn (80:40:40:20 kg ha-1) $\left(T_{2}\right)$, $\mathrm{PSB}+\mathrm{KSB}+75 \% \mathrm{P} \& \mathrm{~K}+$ recommended N \& $\mathrm{Zn}\left(\mathrm{T}_{9}\right)$ and absolute control $\left(\mathrm{T}_{1}\right)$, respectively. Azotobacter+PSB+KSB+75\% N, P \& $\mathrm{K}+$ recommended $\mathrm{Zn}\left(\mathrm{T}_{5)}\right.$ proved second best (2.36 $\left.\mathrm{t} \mathrm{ha}^{-1}\right)$ treatment in influencing grain yield but remained statistically at par with Azotobacter+PSB+KSB+ZnSB+75\% N, P, K \& Zn ( $\left.\mathrm{T}_{6}\right)$, Azotobacter+PSB+75\% N \& P+recommended $K, Z n\left(T_{4}\right)$. The result showed the positive impact of combined application of both biofertilizers and chemical fertilizers on grain yield which showing the conformity of results revealed by Singh et al. (2005), Karwasra et al. (2007), Khan et al. (2007), Kizilkaya (2008), Amanullah et al. (2012), Mirshekari et al. (2012) and Poureidi et al. (2015).

The treatment Azotobacter+PSB+KSB+ZnSB+75\% N, $P, K$ \& $\mathrm{Zn}\left(\mathrm{T}_{6}\right)$ resulted in highest (4.36 $\mathrm{t} \mathrm{ha}^{-1}$ ) straw yield, which however statistically recorded significantly higher straw yield thanall other treatments except Azotobacter+PSB+75\% N \& $\mathrm{P}+$ recommended $\mathrm{K}, \mathrm{Zn}\left(\mathrm{T}_{4}\right)$ and Azotobacter+PSB+KSB+75\% N, P \& K+recommended $\mathrm{Zn}\left(\mathrm{T}_{5}\right)$. The treatment Azotobacter+PSB+KSB+ZnSB+75\% N, P, K \& $\mathrm{Zn}\left(\mathrm{T}_{6}\right)$ resulted $7.72 \%, 23.14 \%, 95.36 \%$ and $270.4 \%$ higher than Azotobacter+PSB+KSB+75\% N, P \& K+recommended $\mathrm{Zn}\left(\mathrm{T}_{5}\right)$, Azotobacter+KSB+75\% N \& $\mathrm{K}+$ Recommended $\mathrm{P}$ \& $\mathrm{Zn}$ $\left(\mathrm{T}_{7}\right)$, recommended N:P:K:Zn (80:40:40:20 kg ha-1) $\left(\mathrm{T}_{2}\right)$ and absolute control $\left(\mathrm{T}_{1}\right)$, respectively. Azotobacter+PSB+KSB+75\% $\mathrm{N}, \mathrm{P} \& \mathrm{~K}+$ recommended $\mathrm{Zn}\left(\mathrm{T}_{5}\right)$ proved second best $(4.28 \mathrm{t}$ $\mathrm{ha}^{-1}$ ) treatment in influencing straw yield. The result revealed that the combined application of biofertilizers and chemical fertilizers had significantly positive impact on straw yield. This result was the confirmation of the result by Singh et al. (2000), who observed that the inoculated oat gave higher straw yield than the control.

Azotobacter+PSB+KSB+ZnSB+75\% N, P, K \& $\mathrm{Zn}\left(\mathrm{T}_{6}\right)$ resulted in highest (6.87 $\mathrm{tha}^{-1}$ ) biological yield which was statistically at par with Azotobacter+PSB+KSB+75\% N, P \& K+recommended $\mathrm{Zn}\left(\mathrm{T}_{5}\right)$. Azotobacter+PSB+KSB+ZnSB+75\% N, P, K \& Zn $\left(\mathrm{T}_{6}\right)$ on the other hand, was recorded $259.60 \%, 85.75 \%$, $60.79 \%, 14.60 \%, 43.42 \%, 55.98 \%$ higher grain yield over control $\left(T_{1}\right)$, recommended N:P:K:Zn (80:40:40:20 kg $\left.\mathrm{ha}^{-1}\right)\left(\mathrm{T}_{2}\right)$, Azotobacter $+75 \% \mathrm{~N}+$ recommended $\mathrm{P}, \mathrm{K}, \mathrm{Zn}$ $\left(\mathrm{T}_{3}\right)$, Azotobacter+PSB+75\% N \& P+recommended $\mathrm{K}, \mathrm{Zn}$ $\left(T_{4}\right), P S B+Z n S B+75 \% P$ \& $Z n+$ recommended $N \& K\left(T_{10}\right)$, $\mathrm{KSB}+\mathrm{ZnSB}+75 \% \mathrm{~K} \& \mathrm{Zn}+$ recommended $\mathrm{N} \& \mathrm{P}\left(\mathrm{T}_{11}\right)$ respectively. Azotobacter+PSB+KSB+75\% N, P \& K+recommended $\mathrm{Zn}\left(\mathrm{T}_{5}\right)$ proved second best $\left(6.60 \mathrm{t} \mathrm{ha}^{-1}\right)$ treatment in influencing total yield. Mirshekari et al. (2012), Azimzadeh et al. (2012) and Ghaderi et al. (2012) reported biofertilizer inoculation significantly increase biological yield which was supported by Radwan et al. (2013) and the present research result was in favour with these previous responses.

The highest (0.38) harvest index was found non-significant in the treatment with recommended N:P:K:Zn (80:40:40:20 kg $\left.\mathrm{ha}^{-1}\right)\left(\mathrm{T}_{2}\right)$ and Azotobacter+KSB+75\% N \& K+recommended P \& $\mathrm{Zn}\left(\mathrm{T}_{7}\right)$ and lowest $(0.35)$ value of recorded with the treatment $\mathrm{PSB}+\mathrm{KSB}+75 \% \mathrm{P} \& \mathrm{~K}+$ Recommended N \& Zn $\left(\mathrm{T}_{9}\right)$.

\subsection{Economics}

Highest ( $₹ 30,520 \mathrm{ha}^{-1}$ ) cost of cultivation was found with recommended N: P: K: Zn (80:40:40:20) and lowest (₹ 23,857 $\mathrm{ha}^{-1}$ ) with absolute control. The lowest cost of cultivation among the treated plots found with Azotobacter+PSB+KSB+ZnSB+75\% N, P, K \& Zn followed by KSB+ZnSB+75\% K \& Zn+recommended $N$ \& $P$ (Table 2). The highest ( $₹ 57403.56$ ha $^{-1}$ ) gross return found also from Azotobacter+PSB+KSB+ZnSB+75\% N, P, 


\begin{tabular}{lcccc}
\hline \multirow{3}{*}{$\begin{array}{l}\text { Table 2: Effect of biofertilizers on economics of oat } \\
\text { Cultivation (pooled data of 2014-15 and 2015-16) }\end{array}$} \\
\begin{tabular}{l}
\multicolumn{4}{c}{$\begin{array}{l}\text { Economics } \\
\text { Treat- }\end{array}$} \\
ments
\end{tabular} & $\begin{array}{c}\text { Cost of } \\
\text { cultivation }\end{array}$ & $\begin{array}{c}\text { Gross } \\
\text { return }\end{array}$ & $\begin{array}{c}\text { Net } \\
\text { return }\end{array}$ & $\begin{array}{c}\text { Return } \\
\text { per rupee } \\
\text { invested }\end{array}$ \\
\hline$T_{1}$ & 23857 & 18595.22 & -5361.78 & 0.84 \\
$T_{2}$ & 30520 & 40021.85 & 9401.85 & 1.39 \\
$T_{3}$ & 30374.5 & 40508.37 & 10033.87 & 1.38 \\
$T_{4}$ & 30106.9 & 49969.85 & 19762.95 & 1.74 \\
$T_{5}$ & 29830.8 & 52012.85 & 22082.05 & 1.82 \\
$T_{6}$ & 29275.2 & 57403.555 & 28028.355 & 2.02 \\
$T_{7}$ & 30098.9 & 44902.925 & 14704.025 & 1.545 \\
$T_{8}$ & 29818.9 & 44678.11 & 14759.21 & 1.57 \\
$T_{9}$ & 29975.8 & 43478.075 & 13402.275 & 1.515 \\
$T_{10}$ & 29696.3 & 42971.185 & 13174.885 & 1.53 \\
$T_{11}$ & 29663.3 & 38770.37 & 9007.07 & 1.405 \\
\hline
\end{tabular}

Equivalent rate at the time of harvesting; 1 USD=INR 62.27 during 2015; 1 USD=INR 66.25 during 2016)

K \& Zn and the lowest (₹ 18,595.22 ha-1 from absolute control. The second best gross return was resulted from Azotobacter+PSB+KSB+75\% N, P \& K+recommended Zn. On the other hand, the highest ( $₹ 28028.36$ ha $^{-1}$ ) net return was found from Azotobacter+PSB+KSB+ZnSB+75\% N, P, $\mathrm{K} \& \mathrm{Zn}$ followed by Azotobacter+PSB+KSB+75\% N, P \& $\mathrm{K}+$ recommended $\mathrm{Zn}$. However, absolute control showed loss due to low economic yield. In oat cultivation, the highest (₹ 2.02) return rupee ${ }^{-1}$ investment recorded from treatment Azotobacter+PSB+KSB+ZnSB+75\% N, P, K \& Zn. Return rupee ${ }^{-1}$ investment found from recommended $\mathrm{N}$ : P: K: Zn (80:40:40:20) was ₹ 1.39 and the lowest value (₹ $0.84)$ with absolute control. The second best return rupee $^{-1}$ invested was resulted from Azotobacter+ PSB+KSB+75\% N, P $\& \mathrm{~K}+$ recommended $\mathrm{Zn}$. The return rupee ${ }^{-1}$ invested recorded more, when all the biofertilizers applied with the replaced amount of chemical fertilizers over only chemical fertilizer applied treatment which was in concurrent with the result proposed by Ghaderi et al. (2012).

\section{Conclusion}

Application of Azotobacter+PSB+KSB+ZnSB+75\% N, P, K \& Zn exhibited highest drymatter, number of panicles $\mathrm{m}^{-2}$, grain yield ,straw yield and biological yield $\left(7.30 \mathrm{t} \mathrm{ha}^{-1}\right)$ of oat grain production. The highest gross return, net return and return rupee $^{-1}$ investment in oat grain cultivation was achieved from the same treatment followed by Azotobacter+PSB+KSB+75\% N, P \& K+recommended Zn.

\section{References}

Abdallah, A.M., Mahmoud, G.O., El-Siadi, S.A., Mohamed,
H.F.Y., 2013. Wheat production and plant chemical composition under using different mineral and biofertilizer treatments. Journal of Applied Sciences Research 9(6), 3949-3959.

Agamy, R.A., Mohamed, G.F., Rady, M.M., 2012. Influence of the application of fertilizer types on growth, yield, anatomical structure and some chemical components of wheat (Triticum aestivum L.) grown in newly reclaimed soil. Australian Journal of Basic and Applied Sciences 6(3), 561-570.

Amanullah, A.A., Khan, S., Ahmed, M., Khan, J., 2012. Biofertilizer -a possible substitute of fertilizers in production of wheat variety Zardana in Balochistan. Pakistan Journal of Agricultural Research 25(1), 44-49.

Anonymous, 2011. Vision 2030: In: Pandey, K.C., Roy, A.K. (Ed.), Forage Crops Varieties. IGFRI, Jhanshi, India, 23-27. Available at http://www.igfri.res.in/pdf/Vision-2030.pdf

Anonymous, 2013. Bulletin. Department of Agricultural Research and Education. January - March 2013. http://dare.nic.in/about-us/secretarydesk/januarymarch-2013.

Azimzadeh, S.M., Azimzadeh, S.J., 2012. Study on replacement probability of biofertilizer with chemical fertilizer in bread wheat (Triticum astivum L). Advances in Environmental Biology 6(10), 2602-2610.

Bokhtiar, S.M., Sakurai, K., 2005. Effects of organic manure and chemical fertilizer on soil fertility and productivity of plant and ratoon crops of sugarcane. Archives of Agronomy and Soil Science 51, 325-334.

Cochran, W.G., Cox, G.M., 1992. Experimental Designs, 2nd Edition. Wiley publication. ISBN: 978-0-471-54567-5, 640.

Esmailpour, A., Hassanzadehdelouei, M., Madani, A., 2013. Impact of livestock manure, nitrogen and biofertilizer (Azotobacter spp.) on yield and yield components of wheat (Triticum aestivum L.). Cercetari Agronomice in Moldova 46(2), 5-15.

Ghaderi, D.N., Bakhshandeh, A., Rostami, M.R., 2012. Biofertilizer affects yield and yield components of wheat. International Journal of Agriculture Research and Review 2(Special issue), 699-704.

Goel, A.K., Laura, R.D., Pathak, D.V., Goel, A., 1999. Use of biofertilizers : potential, constraints and future strategies- A review. International Journal of Tropical Agriculture 17(1-4), 1-18.

Karwasra, R.S., Kumar, V., Kumar, A., 2007. Integrated nutrient and cutting management. Forage Research 33(1), 63-64.

Katyal, J.C., Rattan, R.K., 1993. Distribution of zinc in Indian soils. Fertilizer News 38(6), 15-26.

Khan, I., Hassan, G., Khan, M.I., Gul, M., 2007. Effect of wild oat (Avena fatua $\mathrm{L}$.) population and nitrogen levels on some agronomic traits of spring wheat (Triticum aestivum L.). Turkish Journal of Agriculture and Forestry 31, 91-101. Kizilkaya, R., 2008. Yield response and nitrogen concentrations 
of spring wheat (Triticum aestivum) inoculated with Azotobacter chroococcum strains. Ecological Engineering 33(2), 150-156.

Kumar, S., Agrawal, R.K., Dixit, A.K., Rai, A.K., Singh, J.B., Rai, S.K., 2012. Forage Production Technology for Arable Lands. Technology Bulletin No. 01/2012. Indian Grassland and Fodder Research Institute, Jhansi-284003. Page 1.

Mirshekari, B., Hokmalipour, S., Sharifi, R.S., Farahvash, F., Gadim, A.E.K., 2012. Effect of seed bio-priming with plant growth promoting rhizobacteria (PGPR) on yield and dry matter accumulation of spring barley (Hordeum vulgare L.) at various levels of nitrogen and phosphorus fertilizers. Journal of Food, Agriculture \& Environment 10(3\&4), 314-320.

Mirshekari, B., Kouchebagh, S.B., 2013. Sustainable production of new released wheat cultivars by using urea plus nitragin as a biofertilizer. International Journal of Biosciences 3(6), 38-44.

Moghadam, H.R.T., Salimi, H., Kasraie, P., Jamshidpour, F., 2012. Effect of Azospirillum and Azotobacter in combination with nitrogen chemical fertilizer on wheat (Triticum aestivum L.). Research on Crops 13(1), 29-36.

Mohammed, S.S., Osman, A.G., Mohammed, A.M., Abdalla, A.S., Sherif, A.M. and Rugheim, A.M.E., 2012. Effects of organic and microbial fertilization on wheat growth and yield. International Research Journal of Agricultural Science and Soil Science 2(4), 149-154.

Poureidi, S., Yazdanpanah, M., Rokhzadi, A., Amiri, M., Fayazi, H., 2015. Effect of plant growth promoting bacteria (Azospirillum, Azotobacter, Pseudomonas), humic acid and nitrogen fertilizer on growth and yield of wheat.
Bulletin of Environment, Pharmacology and Life Sciences 4(11), 82-87.

Radwan, F.I., Gomaa, M.A., Nasser, M.A., Kandil, E., Lamlom, S.F., 2013. Effect of sowing methods and bio-organic fertilization on growth, yield and yield components of wheat (Triticum aestivum L.). Research Journal of Agriculture and Biological Sciences 9(1), 70-78.

Sheoran, R.S., Jatasra, D.S., Rana, D.S., 2000. Effects of nutrient sources on grain yield of cereals. Acta Agronomica, Hangarica 48(1), 165-176.

Singh, S.D., Dubey, S.N., 2007. Soil properties and yield of fodder oat (Avena sativa L.) as influenced by sources of plant nutrient and cutting management. Forage Research 33, 101-103.

Singh, V.P., Verma, S.S., Chandra, R., 2005. Effect of fertility level with biofertilizer and cutting management on seed yield of oat. Forage Research 31(1), 57-58.

Subba Roa, N.S., 2001. An appraisal of biofertilizers in India. The biotechnology of biofertilizers, (Ed.) S. Kannaiyan, Narosa Publishing House, New Delhi.

Tapola, N., Karvonen, H., Niskanen, L., Mikola, M., Sarkkinen, E., 2005. Glycemic responses of oat bran products in type 2 diabetic patients. Nutrition, Metabolism and Cardiovascular Diseases 15, 255-261.

Zduncyzyk, Z., Flis, M., Zielinski, H., Wrsblewska, M., Antoszkiewicz, Z., Juskiewicz, J., 2006. In vitro antioxidant activities of barley, husked oat, naked oat, triticale and buck wheat wastes and their influence on the growth and biomarkers of antioxidant status in rats. Journal of Agricultural and Food Chemistry 54, 4168-4175. 